\title{
EFEKTIVITAS PEMBELAJARAN DALAM JARINGAN (DARING) SELAMA PANDEMI COVID-19 DI SMAN 20 JAKARTA
}

\author{
Titin Supriyatin ${ }^{1(*)}$, Dwi Aprillia Setia Asih ${ }^{2}$ \\ Universitas Indraprasta PGRI Jakarta, Indonesia ${ }^{12}$ \\ titinsupriyatin06@gmail.com ${ }^{1}$, dwiaprillia203@gmail.com²
}

\begin{tabular}{ll}
\hline & \\
Received: & 28 Juli 2021 \\
Revised: & 02 September 2021 \\
Accepted: & 16 September 2021
\end{tabular}

\begin{abstract}
Tujuan penelitian ini adalah untuk menganalisis efektivitas pembelajaran dalam jaringan (daring) selama pandemi Covid-19 dari berbagai perspektif guru, orang tua dan murid di SMAN 20 Jakarta. Penelitian ini merupakan penelitian kualitatif. Adapun subjek dalam penelitian ini adalah 10 guru, 16 orang tua dan 12 siswa di SMAN 20 Jakarta di Jakarta Pusat. Metode yang digunakan dalam penelitian ini adalah metode kualitatif deskriptif dengan menggunakan survei yang dilakukan secara online melalui whatsapp untuk mengetahui efektivitas pembelajaran daring dilihat dari perspektif guru, orang tua/wali murid dan siswa ,sehingga pada akhirnya diperoleh persentase skor jawaban dari beberapa indikator baik kelebihan dan kelemahan pembelajaran daring dari sudut pandang guru, orang tua/wali murid dan siswa. Berdasarkan hasil analisis dan temuan peneliti mengenai efektivitas pembelajaran daring dilihat dari perspektif guru, orang tua/wali murid dan siswa menunjukkan bahwa pembelajaran daring memberikan dampak positif dan negatif baik dari guru, orang tua/wali murid maupun siswa. .kelebihan pembelajaran daring adalah Tidak terikat ruang dan waktu, Menumbuhkan kemandirian siswa Memudahkan akses materi tanpa batas selain itu Juga memberikan dampak negatif di antaranya Keterbatasan guru dalam melakukan kontrol saat berlangsungnya pembelajaran daring, Kemampuan guru terbatas dalam menggunakan teknologi ,Peserta didik kurang aktif dan tertarik mengikuti pembelajaran daring, Latar belakang pekerjaan orang tua (swasta, pemerintah maupun wiraswasta) yang tidak bisa menemani langsung anak mereka dalam pembelajaran daring.
\end{abstract}

Keywords: Effektivitas, Pembelajaran, Daring

(*) Corresponding Author:

Supriyatin, titinsupriyatin06@gmail.com, +62 85771282636

How to Cite: Supriyatin, T., \& Asih, D. A. S. (2021). Efektivitas Pembelajaran Dalam Jaringan (Daring) Selama Pandemi Covid-19 Di SMAN 20 Jakarta. Research and Development Journal of Education, 7 (2), 455-463.

\section{INTRODUCTION}

Tatanan kehidupan di dunia telah berubah semenjak adanya virus Covid-19, tak terkecuali di Indonesia. kegiatan manusia menjadi lumpuh semenjak ada virus Covid-19. Mulai dari terserangnya kesehatan manusia hingga melumpuhkan semua aktivitas kegiatan sosial manusia itu sendiri. Persebaran virus yang semakin tak kunjung mereda, membuat pemerintah terpaksa membuat aturan kebijakan dalam rangka memutus mata rantai penyebaran virus Covid-19. Untuk meminimalisir penularan virus Covid-19 tersebut pemerintah membuat kebijakan terhadap masyarakat seperti physical distancing,pembatasan sosial berskala besar (PSBB) dan saat ini adalah Pemberlakuan Pembatasan Kegiatan Masyarakat atau yang kita sebut dengan PPKM level 3 untuk daerah diluar Jawa dan Bali.Kondisi ini mengharuskan masyarakat untuk tetap diam dirumah segala jenis aktivitas kegiatab dilakukan di rumah termasuk diantaranya adalah belajar, bekerja, dan beribadah di rumah.salah satu Akibat dari kebijakan tersebut 
membuat sektor pendidikan seperti sekolah baik dari jenjang SD,SMP Maupun SMA menghentikan proses pembelajaran secara tatap muka. Sehingga Sebagai gantinya, proses pembelajaran dilaksanakan secara dalam jarimgan (daring) yang bisa dilaksanakan dari rumah masing-masing sampai saat ini. bahkan World Health Organization (Organisasi Kesehatan Dunia) juga memberikan pernyataan bahwa kasus korona atau Covid-19 adalah merupakan sebuah pandemi.

Virus Covid-19 juga mempunyai dampak di bidang pendidikan hal ini sesuai dengan pernyataan Perserikatan Bangsa-Bangsa (PBB) menyebutkan bahwa pendidikan menjadi salah satu faktor yang begitu terdampak oleh virus korona. Menurut data Organisasi Pendidikan, Keilmuan, dan Kebudayaan PBB (UNESCO), setidaknya 290,5 juta peserta didik di seluruh dunia yang aktivitas belajarnya menjadi terganggu akibat sekolah yang ditutup sebagai dampak virus korona.Kondisi tersebut telah memicu rasa kekhawatiran yang luar biasa di kalangan masyarakat karena seluruh segmen kehidupan manusia di bumi terganggu, tanpa terkecuali pendidikan. Pemerintah pusat melalui Menteri Pendidikan dan Kebudayaan akhirnya mengeluarkan Surat Edaran Kemendikbud Nomor 40 Tahun 2020 Tentang Pelaksanaan Kebijakan Pendidikan Dalam Masa Darurat Penyebaran Corona Virus Disease (Covid-19). Hasilnya, lembaga pendidikan ramairamai menghentikan kegiatan pembelajaran tatap muka langsung dan menggantinya dengan sistem pembelajaran daring. Utamanya di daerah yang masuk kategori zona kuning dan zona merah. Beberapa daerah yang sudah berstatus zona hijau sudah kembali menjalankan aktivitas pembelajaran langsung. Namun itu pun digelar secara bergilir dan diwajibkan memenuhi standar protokol kesehatan sebagai uapaya pencegahan Covid-19 yang sangat ketat.selain itu saat ini juga pemerintah mewajibkan untuk setiap warga masyarakat untuk melakukan vaksin dari dosis 1 dan dosis 2 di tempat daerah masingmasing aatau sesuai domisili.

Melalui pembelajaran daring, pemerintah berkeyakinan penyebaran virus corona akan dapat ditekan. Menurut Wicaksono (2011) efektivitas model pembelajaran merupakan suatu tolok ukur yang berhubungan dengan tingkat keberhasilan dari suatu proses pembelajaran. Pada saat pandemiCovid-19 ini, model pembelajaran yang tepat untuk diterapkan adalah dengan model pembelajaran daring, seperti menggunakan zoom (Vhalery, Setyastanto, dan Alfilail, 2021), google classroom (Vhalery, Alfilail, dan Robbani, 2021), atau yang lainnya. Hartley menyatakan bahwa model pembelajaran daring merupakan suatu jenis proses belajar mengajar yang memungkinkan tersampainya bahan ajar ke siswa dengan menggunakan media internet, atau media jaringan komputer lain (Wahono, 2011). Selain itu, diharapkan aktivitas dunia pendidikan akan tetap survive mengembangkan potensi sesuai tujuan pendidikan nasional yang tercantum dalam Pasal 3 Undang-Undang Nomor 20 Tahun 2003 tentang Sistem Pendidikan Nasional. Pertanyaannya, efektifkah sistem pembelajaran daring dalam mencapai tujuan nasional.

Pembelajaran daring telah berjalan kurang lebih 18 bulan,hal ini tentunya sangat berpengaruh terhadap guru,orang tua murid/siswa maupun peserta didik itu sendiri. sehingga dalam hal ini peneliti ingin menganalisa effektivitas pembelajaran daring di masa pandemi covid -19 dilihat dari prespektif sudut pandang guru,orang tua murid,siswa di SMA N 20 Jakarta. Jadi tidak hanya dilihat dari sudut pandang guru saja melainkan dari sudut pandang orang tua murid bahkan peserta didik itu sendiri,sehinnga diharapkan nanti dapat ditemukan solusi yang tepat dalam pembelajaran daring dari kelemahankelemahan yang ada. 


\section{METHODS}

Penelitian ini dilaksanakan di salah satu sekolah menengah atas negeri di Jakarta pusat. Metode yang digunakan dalam penelitian ini adalah metode kualitatif deskriptif. Menurut Sukardi (2008) menyatakan bahwa penelitian kualitatif deskriptif adalah merupakan penelitian yang menggambarkan aturan yang menginterpretasikan objek sesuai dengan keadaan yang sebenarnya, dimana dalam hal ini peneliti ingin menganalisa effektivitas pembelajaran daring di masa pandemi covid-19 jika dilihat dari prespektif dari sudut pandang guru,orang tua murid dan peserta didik itu sendiri. untuk mengetahui efektivitas pembelajaran daring dilihat dari perspektif guru,orang tua/wali murid dan siswa di SMA N 20 Jakarta peneliti melakukan survei secara online melalui whatssap. Adapun subjek dalam penelitian ini adalah guru,orang tua serta siswa kelas XI IPS 3 di SMA N 20 Jakarta. sebanyak 10 orang guru, 16 orang tua murid kelas XI IPS 3 dan 12 orang murid kelas XI IPS 3.

\section{RESULTS \& DISCUSSION}

\section{Results}

Pada tahap ini uraian dibagi menjadi tiga bagian, bagian pertama yaitu menjelaskan temuan penelitian berdasarkan analisis angket dari sudut pandang guru sedangkan bagian kedua difokuskan pada hasil penelitian dari sudut pandang orang tua/wali siswa dan bagian ketiga adalah menganalisis hasil angket dari sudut pandang siswa pada penelitian efektivitas pembelajaran daring dilihat dari perspektif guru,orang tua/wali siswa dan siswa pada SMA N 20 Jakarta.

Analisis perhitungan angket variabel tentang pelaksanaan efektivitas pembelajaran daring dilihat dari perspektif guru,orang tua/wali siswa dan siswa pada SMA N 20 Jakarta berdasarkan data angket yang telah kami sebar didapatkan distribusi jawaban yang dapat dilihat pada tabel 1,2, dan 3 . 
Tabel 1.

Angket sudut pandang guru

\begin{tabular}{|c|c|c|c|c|}
\hline \multirow[t]{2}{*}{ Indikator } & \multicolumn{4}{|c|}{ Presentase Skor } \\
\hline & SS & $\mathrm{S}$ & TS & STS \\
\hline Rileks dalam menyampaikan materi & $8,3 \%$ & $83,3 \%$ & $8,3 \%$ & $0 \%$ \\
\hline Tidak terbatas ruang dan waktu & $16,7 \%$ & $75 \%$ & $0 \%$ & $8,3 \%$ \\
\hline Tugas tugas siswa lebih simple & $8,3 \%$ & $75 \%$ & $16,7 \%$ & $0 \%$ \\
\hline $\begin{array}{l}\text { Bisa ditinggal istirahat atau melakukan aktivitas } \\
\text { lainnya }\end{array}$ & $16,7 \%$ & $83,3 \%$ & $0 \%$ & $0 \%$ \\
\hline Sebagian guru gagap teknologi & $0 \%$ & $58,3 \%$ & $33,3 \%$ & $8,3 \%$ \\
\hline $\begin{array}{l}\text { Guru kurang mampu mendesain pembelajaran } \\
\text { yang menarik. }\end{array}$ & $8,3 \%$ & $33,3 \%$ & $58,3 \%$ & $0 \%$ \\
\hline $\begin{array}{l}\text { Tujuan pembelajaran tidak tercapai dengan } \\
\text { maksimal }\end{array}$ & $50 \%$ & $16,7 \%$ & $33,3 \%$ & $0 \%$ \\
\hline $\begin{array}{l}\text { Susah mengontrol kehadiran dan keberadaan } \\
\text { siswa. }\end{array}$ & $33,3 \%$ & $50 \%$ & $16,7 \%$ & $0 \%$ \\
\hline $\begin{array}{l}\text { Kurang mendapat feedback dari peserta didik } \\
\text { dalam prose pembelajaran daring }\end{array}$ & $25 \%$ & $\begin{array}{l}41,7 \% \\
\%\end{array}$ & $33,3 \%$ & $0 \%$ \\
\hline
\end{tabular}

\section{Sumber: Peneliti}

Berdasarkan hasil kuesioner yang telah disebarkan melalui link Google Form di WhatsApp penelitian tentang efektivitas pembelajaran daring dilihat dari perspektif guru menunjukkan bahwa para guru di SMA N 20 Jakarta sebanyak 83,3\% menjawab relatif rileks dalam menyampaikan materi, selain itu materi yang telah dijelaskan bisa dibuka kapan saja sehingga dalam hal ini bisa dikatakan bahwa pelaksanaan pembelajaran daring juga tidak terikat oleh ruang dan waktu karena siswa bisa kapan saja mengakses kembali materi yang telah di share oelh gurunya,dan para guru setuju atas pernyataan tersebut. pembelajaran daring yang kurang maksimal merupakan tantangan tersendiri bagi seorang guru sehingga pada akhirnya mereka memberikan tugas-tugas ke siswanya lebih simpel atau lebih sederhana supaya siswa tidak mengalami kendala dalam pengumpulan tugas pada akhirnya, tetapi ada kelebihannya juga dalam pembelajaran daring bagi seorang guru yaitu saat proses pembelajaran bisa ditinggal istirahat atau melakukan aktivitas lainnya sehingga tidak hanya mengajar saja tetapi bisa melakukan pekerjaan lainnya, kelemahan atau kekurangan pembelajaran daring bagi seorang guru adalah masih ada guru yang masih gagap teknologi, selain itu guru juga masih ada yang kurang mampu mendesain pembelajaran yang menarik minat belajar siswa. ada guru yang menjawab setuju dan sebagian tidak setuju. selanjutnya adalah tujuan pembelajaran tidak tercapai dengan maksimal, guru juga susah mengontrol kehadiran dan keberadaan peserta didik ketika proses pembelajaran secara daring. Kelemahan lainnya pembelajaran daring adalah Kurang mendapat feedback dari peserta didik dalam proses pembelajaran daring. 
Tabel 2.

Angket sudut pandang orang tua

\begin{tabular}{|c|c|c|c|c|}
\hline \multirow[t]{2}{*}{ Indikator } & \multicolumn{4}{|c|}{ Presentase Skor } \\
\hline & SS & $\mathbf{S}$ & TS & STS \\
\hline Kehersamaan dengan anak terus terialin & $41,2 \%$ & $41,2 \%$ & $17,6 \%$ & $0 \%$ \\
\hline $\begin{array}{l}\text { Orang tua bisa meminta bantuan anaknya } \\
\text { disela-sela mereka belajar }\end{array}$ & $11,8 \%$ & $23,5 \%$ & $52,9 \%$ & $11,8 \%$ \\
\hline Orang tua bisa memantau aktivitas anak & $58,8 \%$ & $41,2 \%$ & $0 \%$ & $0 \%$ \\
\hline Orang tua dipaksa menjadi guru dadakan & $17,6 \%$ & $41,2 \%$ & $41,2 \%$ & $0 \%$ \\
\hline $\begin{array}{l}\text { Susah membagi antara pekerjaan dengan } \\
\text { proses mendampingi anak dalam belajar }\end{array}$ & $35,3 \%$ & $52,9 \%$ & $11,8 \%$ & $0 \%$ \\
\hline Banyak orang tua yang gagap teknologi & $35,3 \%$ & $58,8 \%$ & $5,9 \%$ & $0 \%$ \\
\hline $\begin{array}{l}\text { Orang tua harus menyediakan anggaran } \\
\text { lebih kegiatan pembelajaran daring }\end{array}$ & $29,4 \%$ & $64,7 \%$ & $0 \%$ & $5,9 \%$ \\
\hline $\begin{array}{l}\text { Orang tua kesulitan mendampingi } 2 \text { atau } \\
\text { lebih anaknya yg belajar secara bersama }\end{array}$ & $52,9 \%$ & $47,1 \%$ & $0 \%$ & $0 \%$ \\
\hline
\end{tabular}

\section{Sumber: Peneliti}

Berdasarkan hasil angket yang telah disebarkan melalui link Google Form di WhatsApp penelitian tentang efektivitas pembelajaran daring dilihat dari perspektif orang tua/wali siswa di SMA N 20 Jakarta menunjukkan bahwa pembelajaran secara daring mempunyai kelebihan atau berdampak positif bagi orang tua/wali siswa yaitu adanya rasa kebersamaan dengan anak terus terjalin, tidak hanya itu pembelajaran daring juga membuat Orang tua bisa memantau aktivitas anak karena belajar di rumah memberikan kemudahan bagi orang tua untuk memantau belajar siswa secara langsung, selain itu ketika anak belajar di dalam rumah sesekali orang tua bisa meminta bantuan dalam membantu pekerjaan rumah misalkan menyapu atau hanya sekedar membantu menjaga adiknya. Pembelajaran daring telah membuat Orang tua dipaksa menjadi guru, sehingga bagi orang tua yang susah membagi antara pekerjaan dengan proses mendampingi anak dalam belajar akhirnya membuat alternatif atau solusi bagi anaknya dengan memberikan les tambahan ke bimbel ataupun les rumahan. selain itu juga Banyak orang tua yang kurang menguasai/menggunakan teknologi digital yang merupakan salah satu kendala dalam pembelajaran daring, tidak hanya itu pembelajaran daring juga membawa dampak negatif bagi orang tua/wali siswa yaitu Orang tua harus menyediakan anggaran lebih kegiatan pembelajaran daring karena harus menyediakan kuota internet dalam proses pembelajaran daring atau bahkan ada yang berlangganan wifi guna menunjang kelancaran dalam prosespembelajaran daring. Kendala lainnya adalah, orang tua kesulitan mendampingi dikarenakan ada 2 atau lebih anaknya yang belajar secara bersamaan melalui pembelajaran daring. 
Tabel 3.

Angket sudut pandang siswa

\begin{tabular}{lllll}
\hline \multicolumn{1}{c}{ Indikator } & \multicolumn{3}{c}{ Presentase skor } \\
\cline { 2 - 5 } & SS & S & TS & STS \\
\hline Siswa merasa lebih santai dan senang & $41,7 \%$ & $58,3 \%$ & $0 \%$ & $0 \%$ \\
$\begin{array}{l}\text { Siswa merasa punya lebih banyak waktu dirumah } \\
\text { bersama keluarganya }\end{array}$ & $8,3 \%$ & $33,3 \%$ & $50 \%$ & $8,3 \%$ \\
$\begin{array}{l}\text { Siswa merasa punya lebih banyak waktu untuk } \\
\text { beristirahat }\end{array}$ & $41,7 \%$ & $50 \%$ & $8,3 \%$ & $0 \%$ \\
$\begin{array}{l}\text { Siswa merasa lebih rileks dan tidak tegang saat } \\
\text { proses pembelajaran daring }\end{array}$ & $66,7 \%$ & $33,3 \%$ & $0 \%$ & $0 \%$ \\
$\begin{array}{l}\text { Siswa merasa boros dikarenakan kuota jadi cepat } \\
\text { habis }\end{array}$ & $33,3 \%$ & $58,3 \%$ & $0 \%$ & $8,3 \%$ \\
$\begin{array}{l}\text { Siswa merasa lebih sulit memahami materi yang } \\
\text { disampaikan oleh guru }\end{array}$ & $41,7 \%$, & $58,3 \%$ & $0 \%$ & $0 \%$ \\
$\begin{array}{l}\text { Siswa merasa sedih karena uang jajan yang } \\
\text { didapatkan berkurang }\end{array}$ & $16,7 \%$ & $33,3 \%$ & $50 \%$ & $0 \%$ \\
$\begin{array}{l}\text { Siswa merasa kegiatan bersosialisasi dengan } \\
\text { teman-temanya terhambat }\end{array}$ & $25 \%$ & $50 \%$ & $25 \%$ & $0 \%$ \\
\hline
\end{tabular}

Sumber: Peneliti

Berdasarkan hasil angket yang telah disebarkan melalui link Google Form di WhatsApp penelitian tentang efektivitas pembelajaran daring dilihat dari perspektif siswa di SMA N 20 Jakarta menunjukkan bahwa pembelajaran secara daring mempunyai kelebihan atau dampak positif bagi siswa yaitu siswa merasa lebih santai dan senang saat pembelajaran daring berlangsung, hal ini dikarenakan siswa tidak bertatap muka secara langsung dengan guru sehingga bisa mengurangi rasa tegang siswa saat belajar. Selain itu siswa juga merasa mempunyai lebih banyak waktu dirumah bersama orang tua. Namun jika orang tua mereka yang memang rutinitasnya bekerja diluar rumah,dalam hal ini tidak mengalami perubahan yang signifikan baik saat tatap muka ataupun secara daring. Kelebihan lainnya pembelajaran daring bagi siswa adalah mereka merasa punya lebih banyak waktu untuk beristirahat,karena pembelajaran daring dilaksanakan hanya 5 jam setiap harinya. Siswa juga merasa lebih rileks dan tidak tegang saat proses pembelajaran daring. Sedangkan dampak negatif atau kelemahan pembelajaran daring dilihat dari sudut pandang siswa adalah Siswa merasa boros dalam penggunaan data internet dikarenakan kuota internet digunakan untuk membuka aplikasi google meet,zoom atau media lainnya yang digunakan saat pembelajaran daring jadi quota internet cepat habis, selain itu siswa juga merasa lebih sulit memahami materi yang disampaikan oleh guru saat pembelajaran daring dikarenakan keterbatasan guru dalam menjelaskan hanya menggunakan metode ceramah apalagi saat pembelajaran mata pelajaran hitung-hitungan. Dan yang paling dirasakan oleh siswa adalah siswa merasa kegiatan bersosialisasi dengan temantemanya terhambat karena siswa berkomunikasi dengan temannya hanya terbatas dengan menggunakan gawai. 


\section{Discussion}

Penelitian ini dilaksanakan secara online via WhatsApp, peneliti tertarik untuk mengetahui hal yang terkait dengan keefektifan pembelajaran daring dilihat dari perspektif guru, orang tua, dan siswa di SMAN 20 Jakarta. Untuk memperoleh informasi tentang pembelajaran daring peneliti mengumpulkan data dengan menyebarkan angket kepada subjek penelitian sebanyak 10 guru, 16 orang tua siswa kelas XI IPS 3 dan 12 siswa kelas XI IPS 3. Berikut penjelasan yang dipaparkan oleh peneliti berdasarkan hasil penelitian yang telah dilakukan.

Berdasarkan hasil penelitian dan analisis hasil angket dilihat dari perspektif guru didapatkan bahwa terdapat dampak positif dan negatif dari pembelajaran daring di SMAN 20 Jakarta. Hal positif yang dirasakan guru yaitu guru rileks dalam menyampaikan materi pembelajaran, pembelajaran tidak terbatas ruang dan waktu, dan dapat ditinggal istirahat atau melakukan aktivitas lain. Adapun hal negatif dari daring yang dirasakan oleh guru masih terdapat guru yang gagap terhadap teknologi sehingga guru kurang mampu mendesain pembelajaran yang menarik sehingga terkadang siswa kurang antusias dalam mengikuti pembelajaran, guru kurang mendapat feedback dari peserta didik dalam proses pembelajaran daring, guru juga susah mengontrol kehadiran dan keberadaan siswa sehingga berdampak pada tujuan pembelajaran kurang tercapai dengan maksimal. Hasil penelitian ini selaras atau diperkuat oleh peneliti sebelumnya. Menurut Mustakim (2020) dalam penelitiannya menyimpulkan bahwa menggunakan media online atau e-learning saat melakukan pembelajaran daring sangat efektif namun terdapat beberapa hal yang harus diperbaiki oleh pendidik untuk memaksimalkan pembelajaran, misalnya dalam pemberian materi dan pemberian tugas pendidik harus lebih mempertimbangkan hal-hal yang dapat terjadi. Selain itu menurut Nguyen (2015) dalam penelitiannya terkait pembelajaran online menyatakan bahwa pembelajaran online sangat mudah dilaksanakan namun tidak dapat dikatakan lebih efektif jika dibandingkan pembelajaran secara langsung atau tatap muka karena perkembangan yang didapatkan oleh siswa saat pembelajaran secara online sangat bergantung pada situasi dan kondusi siswa itu sendiri.

Berdasarkan hasil penelitian dan analisis hasil angket dilihat dari perspektif orang tua didapatkan dampak positif yang dirasakan dari pembelajaran daring antaralain: orang tua merasakan kebersamaan dengan anak terus terjalin, mampu memantau aktivitas anak dan meminta bantuan kepada anak disela-sela pembelajaran. Adapun dampak negatif dari pembelajaran daring orang tua dipaksa menjadi guru dadakan, hal ini membuat beberapa orang tua merasa kewalahan jika materi yang sedang dibahas tidak memahami/mengerti. Orang tua juga susah membagi waktu pekerjaan dengan proses mendampingi anak dalam belajar karna waktu yang bersamaan bahkan kesulitan mendampingi dua anak atau lebih dalam belajar secara bersamaan, selain itu banyak orang tua yang masih gagap teknologi sehingga kewalahan dalam mendampingi anak saat pembelajaran, serta orang tua harus menyediakan anggaran lebih untuk kegiatan pembelajaran daring.

Berdasarkan hasil penelitian dan analisis hasil angket dilihat dari perspektif siswa didapatkan dampak positif yang dirasakan dari pembelajaran daring antaralain: siswa merasa lebih santai dan senang saat pembelajaran, rileks dan tidak tegang karena siswa dapat menyimak dan memahami pembelajaran sambil makan, minum, jika tidak paham bisa langsung bertanya dengan orang tua atau seseorang yang lebih paham. Siswa lebih banyak waktu untuk keluarga dan beristirahat. Dampak positif ini senada dengan Mustakim (2020) melakukan penelitian terkait penggunaan media online secara umum untuk proses belajar mengajar selama pandemi. Wicaksana, Atmadja, Lestari, Tanti, Efektivitas Pembelajaran Daring \& Odrina (2020) melakukan penelitian terkait 
efektivitas pembelajaran menggunakan moodle terhadap motivasi dan minat bakat peserta didik di tengah pandemiCOVID-19. Penelitian yang mereka lakukan adalah penelitian yang berfokus pada media e-learning madrasah dan mata pelajaran matematika. melalui penelitian ini diharapkan pembaca dapat mengetahui seberapa efektifkah media e-learning madrasah apabila digunakan untuk pembelajaran matematika secara daring. Adapun dampak negatif dari pembelajaran daring yang dirasakan oleh siswa yaitu siswa lebih sulit memahami materi saat dijelaskan oleh guru terkadang karna saat guru menjelaskan terkendala dengan kurang baiknya jaringan internet sehingga siswa kurang memahami apa yang sedang disampaikan oleh guru, siswa merasa boros kuota dan merasa sedih karena uang jajannya berkurang, serta merasa kegiatan bersosialisasi dengan teman-temannya terhambat.

\section{CONCLUSION}

Berdasarkan hasil analisis dan temuan peneliti mengenai efektivitas pembelajaran daring yang dilihat dari perspektif guru,orang tua/wali murid dan siswa menunjukkan bahwa pembelajaran daring memberikan dampak positif dan negatif baik dari guru,orang tua/wali murid maupun siswa. .kelebihan pembelajaran daring adalah tidak terikat ruang dan waktu, Menumbuhkan kemandirian siswa, Memudahkan akses materi tanpa batas selain itu juga memberikan dampak negatif diantaranya Keterbatasan guru dalam melakukan kontrol saat berlangsungnya pembelajaran daring, Kemampuan guru terbatas dalam menggunakan teknologi ,Peserta didik kurang aktif dan tertarik mengikuti pembelajaran daring, Latar belakang pekerjaan orang tua (swasta, pemerintah maupun wiraswasta) yang tidak bisa menemani langsung anak mereka dalam pembelajaran daring. Dalam artikel ini penulis menyampaikan saran bagi para pemangku pendidikan adalah Pengaturan sistem pembelajaran daring harus jelas dan tepat sasaran, agar kedepannya sistem ini dapat menjadi alternatif metode pembelajaran yang tepat.

\section{ACKNOWLEDGEMENT}

Penelitian ini telah diseminarkan pada Duconomics Sci-meet 2021, sebuah pertemuan ilmiah bidang pendidikan dan ekonomi. Hasil dari perhelatan tersebut adalah publikasi ilmiah dalam bentuk prosiding pada situs https://s.id/Duconomics. Naskah ilmiah ini merupakan hasil tindak lanjut dari perhelatan tersebut dengan beberapa penyempurnaan.

\section{REFERENCES}

Mustakim. (2020). Jurnal Efektivitas Pembelajaran Daring Menggunakan Media Online Selama Pandemi Covid-19 pada Mata Pelajaran Matematika. 2 (1):1-12.

Nguyen, T. (2015). The Effectiveness of Online Learning: Beyond no significant difference and future horizons. MERLOT Journal of Online Learning and Teaching, 11(2), 309-319.

Sukardi. (2008). Metodelogi Penelitian Pendidikan. Bumi Aksara : Jakarta.

Surat Edaran Kendikbud No. 4 Tahun 2020. Pelaksanaan Kebijakan Pendidikan dalam Masa Darurat Penyebaran Corona Virus Disease Covid 19. Diakses Pada Tanggal 20 Juni 2020 dari http://pusdiklat.kemendikbud no-4-tahun-2020-tentang- 
pelaksanaan-kebijakan-pendidikan-dalam-masa-darurat-penyebaran-corona-virusdisease-covid-19/

Wahono, S. (2011). "Pengantar E-Learning dan Pengembangannya,". (Online:http://www.ilmukomputer.com).

Wicaksana, J. E., Atmadja, P., Lestari, W., Tanti, L. A., \& Odrina, R. (2020). Efektivitas Pembelajaran Menggunakan Moodle Terhadap Motivasi dan Minat Bakat Peserta Didik di Tengah Pandemi. Jurnal Edukasi dan Teknologi Pembelajaran, 1(2), 117124. DOI: https://doi.org/10.37859/eduteach.v1i2.1937

Wicaksono. (2011). Efektifitas metode pembelajaran. Jakarta: Wordpress.

Vhalery, R., Alfilail, S. N., \& Robbani, H. (2021). Persepsi Mahasiswa tentang Pembelajaran Online Google Classroom pada Minat dan Motivasi Belajar. INTELEKTIUM, 2(1), 28-36.

Vhalery, R., Setyastanto, A. M., \& Alfilail, S. N. (2021). PEMBELAJARAN BERBASIS ONLINE "ZOOM" PADA KESIAPAN BELAJAR MAHASISWA DI MASA PANDEMI COVID-19. Research and Development Journal of Education, 7(1), 215-225. 